\title{
Tendency to Choose Big Audit Firms: Case of Indonesia
}

\author{
Putu Agus Ardiana \\ Faculty of Economics and Business, Udayana University, Indonesia \\ E-mail: ardiana.idea@gmail.com
}

Received: Sep. 8, 2014

Accepted: Oct. 12, 2014 Published: December 1, 2014

doi:10.5296/ajfa.v6i2.6287

URL: http://dx.doi.org/10.5296/ ajfa.v6i2.6287

\begin{abstract}
This paper investigates the tendency of companies to choose a big audit firm as their external auditor under the condition of their income smoothing tendency and risk tolerance to business and financial risks. Using 2,240 company-year observations listed on the Indonesian Stock Exchange, it generally reveals that companies with lower tendency to smooth earnings and companies with intolerable risk tend to choose big audit firms. These results are also consistent after controlling the asset size of companies (clients). In addition, companies would tend to show indifferent preference when the opportunistic and non-opportunistic income smoothing tendencies are in the same proportion. This paper also implies that audit firms tend to accept audit offers from clients with intolerable risk but with greater asset size to compensate higher risk. The situation where big audit firms accept clients with intolerable risk level indicates that non-big audit firms are not capable of doing so and audit firms in Indonesia operate in weak litigation environment.
\end{abstract}

Keywords: Income smoothing tendency, Business and financial risk tolerance, Client size, Audit firm size 


\section{Introduction}

The need of audit service from external auditors comes from a consequence of asymmetry information between stockholders or principal (external party) and management or agent (internal party). The asymmetry information leads to the need of independent party to provide assurance services that the financial statements prepared by the agent have been in accordance with accounting standards. In many cases, asymmetry information between principal and agent causes moral hazard in the sense that agent tend to act for their personal interest which is unlikely in the line with principal's interest (Jensen \& Meckling, 1976; Watts \& Zimmerman, 1983).

Agency theory predicts that the awareness of principal and agent about the existence of moral hazard might be achieved by goal congruence or harmonization. The more complex the agency conflict, the greater the demand on external audit and the quality of audit (Palmrose, 1984; Francis \& Wilson, 1988; DeFond, 1992; and Craswell et al., 1995). A number of research publications about audit quality and auditor reputation (proxied by audit firm size or auditor brand name) show that big audit firms or brand name auditors have greater monitoring strength which is capable of resulting greater information quality and credibility (DeAngelo, 1981; Dopuch \& Simunic, 1982; Titman \& Trueman, 1986; and Beatty, 1986). More specifically, Beatty (1986) shows that big audit firms or brand name auditors tend to provide audit services to clients with greater asset size but lower financial and litigation risks.

An interesting empirical finding reveals that brand name audiors effectively reduce the tendency of companies to commit earnings management (Dopuch \& Simunic, 1982). This is because the brand name auditors have greater resources with better quality to execute more complex audit procedures. Becker et al. (1998) find that discretionary accruals are higher for companies audited by small audit firms or non-brand name auditors. The existence of higher discretionary accruals indicates greater tendency of earnings management.

Risk is basically the variation of an actual value from its expected value and each individual has different preference of risk level. Even though companies do not have debt at all, those companies remain have risk associated with the business that the companies run (so called business risk). When companies start to have debt, those companies start to bear financial risk. There is a trade-off between business risk and financial risk. For example, mining companies have greater business risk than companies in consumer goods because mining companies are highly depended on climate, weather, temperature, and other extraordinary factors that are very difficult to control. If mining companies with greater business risk want to have debt, their financial risk tolerance is lower than those with lower business risk. Beatty (1986) finds that brand name auditors prefer choosing clients with lower financial and litigation risks.

Previous research publications about the relationship between earnings management and audit quality (measured by audit firm size) result in endless debates regarding earnings management measurement and a critical question about whether or not brand name auditors really reflect better audit quality. Most researchers measure earnings management indication by discretionary accruals. Other researchers show that discretionary accruals fail to measure earnings management accurately (Dechow et al., 1995; Thomas \& Zhang, 2000; Dechow et 
al., 2003; Stubben, 2008). Consequently, researchers such as Stubben (2008) and McNichols \& Stubben (2008) propose an alternative technique which is arguably more accurate in measuring earnings management. They measure earnings management tendency by residuals resulted from single linear regression between annual change in accounts receivable and annual change in sales revenue. Meanwhile, Tucker \& Zarowin (2006) measure income smoothing tendency by determining the correlation between the change in discretionary accruals and the change in pre-managed earnings. They find that income smoothing tendency exists when the change in discretionary accruals and the change in pre-managed earnings have negative correlation.

This research proposes an absolute value of earnings forecast errors as a measure of income smoothing tendency which revises the management forecast errors proposed by Davidson \& Neu (1993). Davidson \& Neu (1993) measure income smoothing tendency by the residuals resulted from the single linear regression between forecasted earnings and reported earnings. The forecasted earnings are likely very subjective from management or at least they are full of assumptions and judgements which reduce the accuracy of the measurement. This research uses absolute value of residuals from the regression between after-tax earnings and the reporting period (so called the absolute value of earnings forecast errors) and these absolute residuals are considered more objective because the ordinary least square will determine a linear line with the least sum of squared residuals objectively. If the absolute value of earnings forecast errors equals zero, it strongly indicates that management commits income smoothing. In other words, the lower the absolute value of earnings forecast errors or the more the absolute value of earnings forecast errors approaches zero, the greater the tendency of income smoothing while the greater the absolute value of earnings forecast errors, the less the tendency of income smoothing.

Previous studies about the relationship between company risks and audit quality often divide company risks as business and financial risks and measure audit quality by audit firm size. Greater financial risk would not be a problem for companies with lower business risk but indeed would be a problem if the business risk is also high. This indicates that stakeholders have tolerance level for those two risks. This research uses risk tolerance instead of either business risk or financial risk as a proxy of company risk. Business risk is measured by the standard deviation of profit before interests and taxes in four quarterly reporting periods of each company. The arithmetic mean of the business risk of each industry is determined as a measure of average business risk of each industry. A company's business risk is classified as high (low) if the company's business risk is higher than or equal to (lower than) the average business risk of the industry where the company runs it business. Financial risk is measured by total debt to total equity ratio (DER), a common used solvability ratio. A company's financial risk is classified as high (low) if the company's DER is higher than or equal to (lower than) the average DER of the industry where the company runs it business. Tolerable risk refers to a condition in which a company has high business (financial) risk but low financial (business) risk, or it has both low business and financial risks.

Audit firm size in this research does not indicate audit quality but the decision of companies to choose one particular audit firm size (big or small audit firm). This research uses 
companies' asset size (natural logarithm of their asset size) as a control variable. This research is expected to contribute to earnings management techniques and company risk measures and their relationship with the decision to choose an audit firm in Indonesia.

\section{Review of Literatures and Development of Hypotheses}

The demand for audit services is surprisingly driven by the need of assurance services, not due to mandatory rules from an act. Benston (1969) reports that 82 per cent of public companies listed on the New York Stock Exchange (NYSE) were audited by audit firms before the Securities Act 1933 and 1934 were introduced. Therefore, legal forces are not a trigger of the demand for audit services that are provided by independent auditors. Meanwhile, the demand for audit quality is triggered by asymmetry information between stockholders and management.

The agency conflict between those two parties were investigated by Titman \& Trueman (1986), Francis \& Wilson (1988), Bachar (1989), Datar et al. (1991), Feltham et al. (1991), DeFond (1992), Clarkson \& Simunic (1994). DeAngelo (1981) shows that each audit firm has certain specialization that creates certain level of audit quality. Consequently, if a client wants to have a change in audit quality level, it should change the audit firms. In addition, DeAngelo (1981), Dopuch \& Simunic (1982), Titman \& Trueman (1986), and Beatty (1989) find that brand name auditors (audit firms in Indonesia which are affiliated with the big four audit firms) have greater monitoring strength leading to greater information quality and credibility.

\subsection{Earnings Management and Audit Firms}

Earnings management should not be considered taboo considering that there is a trade-off between relevance and reliability in accounting principles. Financial statements prepared by management are expected to provide predictive value, feedback value, and timeliness in order to be relevant for decision making. For the reason of timeliness, management make estimations and judgments to several transactions, e.g. estimation and judgment for the recognition of bad debt expense and allowance for bad debts. These estimations and judgments are the main contributor in earnings management. As long as these estimations and judgments are in the corridor of accounting standard and not for the purpose of earning benefit at the expense of other parties, the earnings management should not be viewed as crime.

Investors generally focus their analyses on earnings informativeness and often ignore the process of how earnings are reported. This often becomes an opportunistic situation for management to commit earnings management. When the asymmetry information is too wide, the chance for earnings management is greater and investors are more negatively impacted.

Earnings management is basically a management activity in choosing an accounting policy from several alternatives allowed by accounting standards to meet stakeholders' interest, especially stockholders as they are the principal. However, asymmetry information makes it possible for management to act for their personal interest through earnings management at the expense of stockholders and other stakeholders. This condition refers to opportunistic 


\section{I Macrothink}

Asian Journal of Finance \& Accounting ISSN 1946-052X 2014, Vol. 6, No. 2

earnings management (Scott, 2000). In more negative connotation, this type of earnings management can be called earnings manipulation. Meanwhile, earnings management should be viewed as a normal management activity if it is undertaken through managing accruals and cash-flow related transactions without any purpose of misleading the users of financial statements and remain in the line with accounting standards.

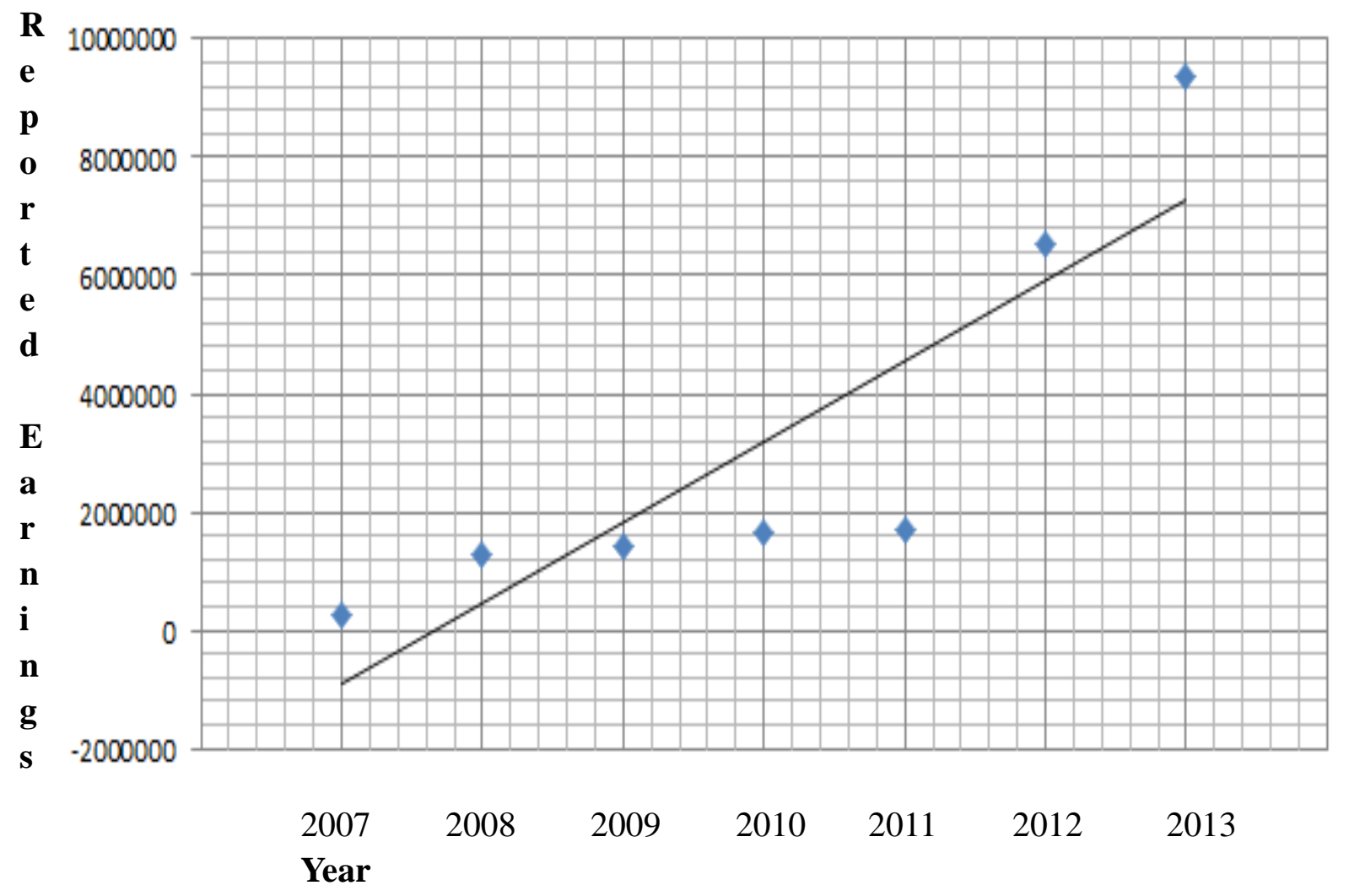

Figure 1. Illustration of Earnings Forecast Errors by Using Scatter Plot and OLS

McNichols \& Stubben (2008) reveal that earnings management affects company's investment decisions. During the period of earnings manipulation, companies found to be involved in accounting irregularities, improper accounting, and restatement of financial statement by Securities and Exchange Commission (SEC) undertook substantial over-investment but after the period of earnings manipulation, this decision dramatically declined. Davidson \& Neu (1993) show that managers tend to reduce their activity of manipulating reported earnings to achieve targeted profit or forecasted earnings when companies where the managers work for are being audited by brand name auditors or big audit firms. According to Davidson \& Neu (1993), it reveals that clients have little or even no chance at all to take benefits from accruals to minimize forecast errors (the difference between reported earnings and forecasted earnings).

Income smoothing is an earnings management technique that is widely used by managers. This type of earnings management comes from a logic reasoning that users of financial statements tend to prefer smooth trend of earnings to the fluctuated one. This research uses the absolute value of earnings forecast errors as the proxy of income smoothing tendency. 
Earnings forecast errors are errors or residuals resulted from the ordinary least square (OLS) between the reported after-tax profits and the period of reporting those profits, as illustrated by Figure 1. The errors or residuals are the difference between the reported after-tax profits and the forecasted after-tax profits (dots lay on the OLS line) in each year of reporting period. Strong tendency of income smoothing is concluded if the difference of the reported after-tax profits and the forecasted after-tax profits is zero (in this case, the reported after-tax profits lay exactly on the OLS line together with the forecasted after-tax profits). If the differences are positive or negative, these errors are then converted to their absolute values. The greater the distance between the reported and the forecasted after-tax profits, the greater the errors or residuals will be. This condition means that the lower the tendency of income smoothing. Therefore, the hypothesis is:

$\mathrm{H}_{1}$ : The greater the absolute value of earnings forecast errors, the lower the tendency of income smoothing, thus the greater the probability of choosing big audit firms.

\subsection{Risk Tolerance and Audit Firms}

Risks faced by companies can be in the form of business and financial risk. Business risk refers to the risk that is inherent to the company's business. Each company has different level of business risk, depending on its business characteristics and complexity. For example, companies in consumer goods industry has lower business risk than that of mining companies. Meanwhile, financial risk refers to the risk faced by companies having debts. If the level of debts is too high and causes inability of the company to pay the debts, the company suffers from bankruptcy risk. It does not necessarily follow that all companies having debts tend to bankrupt. In a certain range (when marginal benefit of debt is greater than the marginal cost of debt), companies having debt may increase their value, but in other certain range (when marginal benefit of debt is less than the marginal cost of debt), the companies may suffer from a decline in their value or an increase of bankruptcy risk. Reilly \& Brown (2009) reveal that high financial risk does not necessarily follow high bankruptcy risk. If companies operating business in certain industry have relatively low inherent business risk, higher financial risk perhaps does not necessarily mean greater probability of being bankrupt. However, if companies have inherently high business risk, the higher financial risk might increase the bankruptcy risk, or at least they are potentially having difficulty in paying their debts.

Table 1. Matrix of Tolerable Business Risk and Financial Risk

\begin{tabular}{|c|c|c|}
\hline Financial Risk $\quad$ Business Risk & HIGH & LOW \\
\hline HIGH & INTOLERABLE & TOLERABLE \\
\hline LOW & TOLERABLE & TOLERABLE \\
\hline
\end{tabular}

Source: Adapted from Reilly \& Brown (2009)

Table 1 above shows that intolerable risk happens when companies have high business risk and financial risk while tolerable risk happens when (1) companies have high financial risk 
but low business risk, or (2) companies have high business risk but low financial risk, or (3) companies have both low business and financial risks. Datar, Feltham, \& Hughes (1991) find that riskier companies require higher audit quality by getting assurance services from bigger audit firms. Big audit firms (those which are affiliated with the big four) are considered to have greater monitoring strength leading to greater information quality and credibility in transmitting more positive signal to stakeholders.

Clarkson \& Simunic (1994) support the research finding of Datar, Feltham, \& Hughes (1991) that in less strong litigation environment, companies audited by big audit firms tend to have higher risk with low ownership retention. Riskier companies require assurance services from big audit firm in order to increase their audit quality leading to an increase in the quality of their financial reporting. The companies expect more new investors are interested in purchasing their stocks. Consequently, the proportion of stocks held by old stockholders tend to decline (lower ownership retention) because the they tend not to increase the stock ownership in companies that they realize having high risk and are pleased to welcome new stockholders to share the risk. Therefore, the hypothesis is:

$\mathrm{H}_{2}$ : Companies with intolerable risk tend to choose big audit firms.

\section{Research Method}

This research uses 2,240 company-year observations which were consistently listed on the Indonesian Stock Exchange from 2007 to 2013. Table 2 shows that the number of company-year observations consistently listed were 2,240 observations, which are about 75,12 per cent of total company-year observations from 2007 to 2013. This research uses logit regression to investigate the probability of companies with certain degree of income smoothing tendency and risk tolerance to choose big audit firms.

There are three variables operated in this research. The first two variables are independent variable, which are (1) the absolute value of earnings forecast errors (ABSEFE) as a measure of income smoothing tendency, and (2) dummy variable of risk tolerance (DTOL) as a measure of risk tolerance to business and financial risks. Meanwhile, the last variable is dependent variable, which is dummy variable of audit firm size (DAUDITOR) as a measure of audit firm size. In addition to independent and dependent variables, this research introduces one control variable, which is company's or client's size which is measured by the natural logarithm of total assets (SIZE).

Table 2. Number of Samples

\begin{tabular}{|c|c|c|c|c|c|c|c|c|}
\hline & 2007 & 2008 & 2009 & 2010 & 2011 & 2012 & 2013 & Total \\
\hline Number of listed companies & 383 & 396 & 398 & 420 & 440 & 462 & 483 & 2,982 \\
\hline $\begin{array}{c}\text { Number of companies with incomplete data } \\
\text { Number of (sample) companies consistently } \\
\text { listed from 2007 to 2013 }\end{array}$ & 320 & 320 & 320 & 320 & 320 & 320 & 320 & 2,240 \\
\hline
\end{tabular}

The absolute value of earnings forecast errors (ABSEFE) is the absolute value of the errors or 
residuals (differences between the reported after-tax profits and the estimated after-tax profits from 2007 to 2013) resulted from ordinary least square regression of observed or reported after-tax profits and the period of reported profits from 2007 to 2013. The greater the distances (absolute value of the differences) between the reported after-tax profits and the estimated ones, the lower the income smoothing tendency. The strongest tendency of income smoothing is when the reported and the estimated after-tax profits are exactly the same amount.

Dummy variable of risk tolerance (DTOL) is a measurement of a company's risk tolerance to business and financial risks. DTOL equals one if the company has intolerable risk and equals zero if it has tolerable risk. The risk is intolerable if only the business risk and financial risk are high. Meanwhile, the risk is tolerable if the business risk is high but the financial risk is low or vice versa, or if both business risk and financial risk are low. Business risk is measured by the standard deviation of profit before interests and taxes in four quarterly reporting periods of each company. The arithmetic mean of the business risk of each industry is determined as a measure of average business risk of each industry. A company's business risk is classified as high (low) if the company's business risk is higher than or equal to (lower than) the average business risk of the industry where the company runs it business. Financial risk is measured by total debt to total equity ratio (DER), a common used solvability ratio. A company's financial risk is classified as high (low) if the company's DER is higher than or equal to (lower than) the average DER of the industry where the company runs it business.

Table 3. The Big Four - Affiliated Audit Firms in Indonesia

\begin{tabular}{|l|l|l|}
\hline \multicolumn{1}{|c|}{ Big Four Audit Firms } & \multicolumn{1}{|c|}{$\begin{array}{c}\text { Indonesian Audit } \\
\text { Firms }\end{array}$} & \multicolumn{1}{c|}{ Address } \\
\hline $\begin{array}{l}\text { PricewaterhouseCoopers } \\
(\text { PwC) }\end{array}$ & $\begin{array}{l}\text { KAP Tanudiredja, } \\
\text { Wibisana \& Rekan }\end{array}$ & $\begin{array}{l}\text { Plaza 89 Jl. H.R. Rasuna Said Kav. X-7 No. 6 Jakarta } \\
12940-\text { Indonesia P.O. Box 2473 JKP 10001 Phone: } \\
+62215212901 \text { Fax: +62 21 52905555 / 52905050 }\end{array}$ \\
\hline Deloitte & $\begin{array}{l}\text { KAP Osman Bing } \\
\text { Satrio }\end{array}$ & $\begin{array}{l}\text { The Plaza Office Tower 32nd Floor Jl. M.H. Thamrin } \\
\text { Kav 28-30 Jakarta Indonesia. Phone number: +62 21 } \\
\text { 2992 3100. }\end{array}$ \\
\hline $\begin{array}{l}\text { Ernst \& Young } \\
\text { Klynveld, Peat, Marwick, } \\
\text { Goerdeler (KPMG) }\end{array}$ & $\begin{array}{l}\text { KAP Sidharta dan } \\
\text { Widjaja }\end{array}$ & $\begin{array}{l}\text { Indonesia Stock Exchange Building Tower 2, 7th Floor } \\
\text { Jl. Jend. Sudirman Kav. 52-53 Jakarta 12190 Indonesia } \\
\text { Phone: +62 21 5289 5000 }\end{array}$ \\
\hline
\end{tabular}

Source: Indonesian Institute of Certified Public Accountants (2013)

Dummy variable of audit firm size (DAUDITOR) is a measurement of audit firm size. DAUDITOR equals one if the company is audited by an audit firm which is affiliated with a big four audit firm and equals zero if the company is not audited by an audit firm which is affiliated with a big four audit firm. The list of Indonesian audit firms which have affiliation with big four audit firms is presented on Table 3. 
Descriptive statistics in Table 4 shows that the absolute value of earnings forecast errors (ABSEFE) has an arithmetic mean of Rp 9,762,564.69 thousand and standard deviation of Rp $44,265,436.53$ thousand. This relatively high average of ABSEFE indicates that income smoothing tendency is relatively low on average. Meanwhile, the relatively high standard deviation of ABSEFE is confirmed by wide range between its maximum and minimum value.

Over 2,240 firm-year observations, 505 firm-year observations are intolerance to business and financial risks while 1,735 firm-year observations are tolerance to them. In addition, there are 1,356 out of 2,240 firm-year observations which choose big audit firms while 884 firm-year observations choose non-big audit firm.

Descriptive statistics of client's size is not straight forwardly interpreted because it is measured by the natural logarithm of client's total assets. SIZE has an arithmetic mean of 12.14. This value is equivalent to total assets of Rp 187,034 million. Its standard deviation is considerably low with 0.93 or equivalent to about 2.5 million rupiahs. Its low standard deviation implies that there is no wide range between the maximum and minimum value of client's total assets.

Table 4. Descriptive Statistics

\begin{tabular}{|l|c|c|c|c|}
\hline \multicolumn{1}{|c|}{ Statistics } & ABSEFE $^{\mathrm{b}}$ & DTOL $^{\mathrm{a}}$ & SIZE $^{\mathrm{c}}$ & DAUDITOR $^{\mathrm{a}}$ \\
\hline Number of Observations & 2,240 & 2,240 & 2,240 & 2,240 \\
\hline Number of Observations $\mathrm{D}=1^{\mathrm{a}}$ & - & 505 & - & 1,356 \\
\hline Number of Observations $\mathrm{D}=0^{\mathrm{a}}$ & - & 1,735 & - & 884 \\
\hline Arithmetic Mean & $9,762,564.69$ & 0.23 & 12.14 & 0.61 \\
\hline Standard Deviation & $44,265,436.53$ & 0.42 & 0.93 & 0.49 \\
\hline Median & 1255885.5 & 0 & 11.92 & 1 \\
\hline Maximum Value & 635618708 & 1 & 14.39 & 1 \\
\hline Minimum Value & 901 & 0 & 10.40 & 0 \\
\hline
\end{tabular}

Source: Output of Descriptive Statistics from EViews

Note:

a) For DTOL, $D=1$ refers to intolerable risk, while $\mathrm{D}=0$ refers to tolerable risk.

For DAUDITOR, $\mathrm{D}=1$ refers to big audit firm (affiliated with the big four) whereas $\mathrm{D}=0$ refers to non-big audit firm (not affiliated with the big four)

b) ABSEFE is the absolute value of the difference between reported after-tax profit and predicted after-tax profit under ordinary least square. The numbers are presented in thousand rupiahs.

c) SIZE is the natural logarithm of client's total assets, which is presented in million rupiahs

According to Table 5 below, all independent variables significantly affect the decision to choose audit firm size at 95 per cent of confidence level. These variables consistently show 
significant effect on audit firm choice after controlling client's size. More specifically, ABSEFE has a positive coefficient sign, which implies that the greater the absolute value of the difference between reported after-tax profit and predicted after-tax profit, the lower the income smoothing tendency, and eventually the greater the probability of clients to choose big audit firms. DTOL and SIZE also have positive coefficient sign indicating that clients with intolerable risk and greater asset size has greater tendency to choose big audit firm.

Table 5. Logit Regression of All Independent Variables and Dependent Variable

\begin{tabular}{|c|c|c|c|c|c|c|c|c|}
\hline \multirow{3}{*}{ Variables } & \multicolumn{8}{|c|}{ Dependent Variable: DAUDITOR } \\
\hline & \multicolumn{4}{|c|}{ Before Control Variable } & \multicolumn{4}{|c|}{ After Control Variable } \\
\hline & $\begin{array}{l}\text { Coef } \\
\text { (S.E) }\end{array}$ & z-Stat & Sig & $\begin{array}{l}\text { Odds } \\
\text { Ratio }\end{array}$ & $\begin{array}{l}\text { Coef } \\
\text { (S.E) }\end{array}$ & z-Stat & Sig & $\begin{array}{l}\text { Odds } \\
\text { Ratio }\end{array}$ \\
\hline Intercept & $\begin{array}{l}-0.008452 \\
(0.050083)\end{array}$ & -0.169 & 0.866 & 0.99 & $\begin{array}{r}-1.744730 \\
(0.60743)\end{array}$ & -2.872 & 0.004 & 0.17 \\
\hline ABSEFE & $\begin{array}{c}9.93 \mathrm{E}-09 \\
(1.79 \mathrm{E}-09)\end{array}$ & 5.544 & 0.000 & 1.00 & $\begin{array}{c}1.01 \mathrm{E}-08 \\
(1.79 \mathrm{E}-09)\end{array}$ & 5.614 & 0.000 & 1.00 \\
\hline DTOL & $\begin{array}{c}2.111983 \\
(0.152164)\end{array}$ & 13.88 & 0.000 & 8.26 & $\begin{array}{l}2.121188 \\
(0.15214)\end{array}$ & 13.94 & 0.000 & 8.34 \\
\hline SIZE & & & & & $\begin{array}{l}0.142825 \\
(0.04977)\end{array}$ & 2.870 & 0.041 & 1.15 \\
\hline Pseudo $\mathrm{R}^{2}$ & \multicolumn{4}{|l|}{0.119910} & \multicolumn{4}{|l|}{0.122787} \\
\hline $\mathrm{N}$ & \multicolumn{4}{|l|}{2,240} & \multicolumn{4}{|l|}{2,240} \\
\hline
\end{tabular}

Source: Output of Eviews

Note: The parentheses are the standard errors of corresponding variables. Odds ratio is the exponential form of regression coefficient $[\operatorname{Exp}(\quad)]$

\subsection{Income Smoothing Tendency and Audit Firm Size}

Table 6 shows that ABSEFE, in partial logit regression, has consistent result to the overall test of variables as shown in previous table. ABSEFE has a positive coefficient sign both before and after controlling client's asset size, which implies that the greater the absolute value of the difference between reported after-tax profit and predicted after-tax profit (which also means the lower the income smoothing tendency), greater the probability of clients to choose big audit firms. Consequently the first hypothesis is accepted.

Income smoothing might be opportunistic or non-opportunistic form. It is opportunistic income smoothing if company's financial statement preparer takes benefit from either increasing or decreasing the reported profit at the expense of stakeholders while in non-opportunistic form of income smoothing, the financial preparer uses accounting accruals to best reflect the company's current economic situation. There is a trade-off between opportunistic and non-opportunistic income smoothing that the greater the opportunistic income smoothing, the lower the non-opportunistic income smoothing. Consequently, there 
will be a point where opportunistic equal to non-opportunistic income smoothing. This is the point where the odds ratio (exponential form of ABSEFE's regression coefficient) equals 1.00 as explained below.

Table 6. Partial Logit Regression of Income Smoothing Tendency and Audit Firm Size

\begin{tabular}{|c|c|c|c|c|c|c|c|c|}
\hline \multirow{3}{*}{ Variables } & \multicolumn{8}{|c|}{ Dependent Variable: DAUDITOR } \\
\hline & \multicolumn{4}{|c|}{ Before Control Variable } & \multicolumn{4}{|c|}{ After Control Variable } \\
\hline & $\begin{array}{l}\text { Coef } \\
\text { (S.E) }\end{array}$ & z-Stat & Sig & Odds Ratio & $\begin{array}{l}\text { Coef } \\
\text { (S.E) }\end{array}$ & z-Stat & Sig & Odds Ratio \\
\hline Intercept & $\begin{array}{r}0.454 \\
(0.045)\end{array}$ & 10.08 & 0.000 & 1.57 & $\begin{array}{c}-0.96 \\
(0.5779)\end{array}$ & -1.66 & 0.097 & 0.38 \\
\hline ABSEFE & $\begin{array}{c}6.83 \mathrm{E}-09 \\
(1.72 \mathrm{E}-09)\end{array}$ & 3.96 & 0.000 & 1.00 & $\begin{array}{c}6.91 \mathrm{E}-09 \\
(1.73 \mathrm{E}-09)\end{array}$ & 4.01 & 0.000 & 1.00 \\
\hline SIZE & & & & & $\begin{array}{c}0.12 \\
(0.048)\end{array}$ & 2.45 & 0.014 & 1.13 \\
\hline Pseudo $\mathrm{R}^{2}$ & \multicolumn{4}{|l|}{0.007380} & \multicolumn{4}{|l|}{0.0075} \\
\hline $\mathrm{N}$ & \multicolumn{4}{|l|}{2,240} & \multicolumn{4}{|l|}{2,240} \\
\hline
\end{tabular}

Source: Output of EViews

Note: The parentheses are the standard errors of corresponding variables. Odds ratio is the exponential form of regression coefficient $[\operatorname{Exp}(\quad)]$

\subsubsection{Condition One: Strong Litigation Environment}

In a country with strong litigation environment, audit firms will tend to have clients with lower risk. The cost of litigation is very high so that the audit firms are not interested in providing audit service to higher risk clients. In this case, opportunistic income smoothing is considered to have higher risk than the non-opportunistic income smoothing.

Figure 2 clearly shows that as (opportunistic) income smoothing tendency declines, the probability of companies to choose big audit firm increases. This is consistent with the positive regression coefficient sign of ABSEFE that the greater the absolute value of earnings forecast errors, the lower the (opportunistic) income smoothing tendency, and ultimately the greater the probability of companies to choose big audit firm.

Figure 2 below comprises three important parts. The first part is when odds ratio is less than one, the second part is when odds ratio equals one, and the last part is when odds ratio is greater than one. The first part, with odds ratio is less than one (when the probability of companies choosing non-big audit firms is greater than the probability of companies choosing big audit firms), shows that opportunistic income smoothing is greater than non-opportunistic income smoothing. In this case, companies tend to choose non-big audit firms than the big audit firms. One possible reason is that non-big audit firms with weaker monitoring strength are less capable of detecting such practice of income smoothing. The other possible reason is 


\section{Macrothink}

that big audit firms tend to reject audit offer from clients with greater risk (greater opportunistic income smoothing tendency).

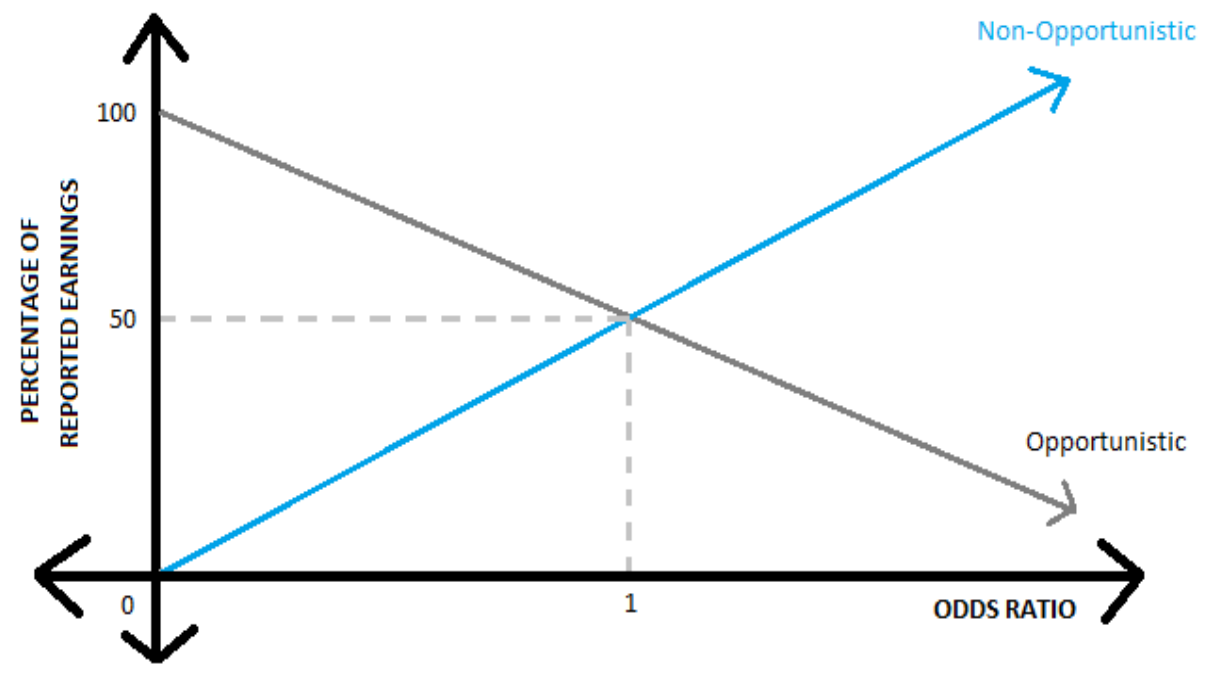

Figure 2. Illustration about the Relationship between Types of Income Smoothing and Odds Ratio in Strong Litigation Environment

The second part, with odds ratio equals one (when the probability of companies choosing non-big audit firms equals the probability of companies choosing big audit firms), shows that opportunistic income smoothing equals non-opportunistic income smoothing. In this case, companies have indifferent preference to audit firm size. The odds ratios of ABSEFE of 1.00 both before and after controlling client's asset size on Table 5 and Table 6 above indicate a situation that the portion of opportunistic and non-opportunistic income smoothing tendencies are the same.

The last part, with odds ratio is greater than one (when the probability of companies choosing big audit firms is greater than the probability of companies choosing non-big audit firms), shows that non-opportunistic income smoothing is greater than opportunistic income smoothing. In this case, companies tend to choose big audit firms than non-big audit firms. One possible reason is that big audit firms tend to provide audit service to less risky clients (clients with greater non-opportunistic income smoothing tendency) in an environment with high litigation cost.

\subsubsection{Condition Two: Weak Litigation Environment}

In a country with weak litigation environment, audit firms may have clients with higher risk. The cost of litigation is relatively low so that the audit firms may diversify their client portfolio. In the case of having riskier clients, audit firms would charge higher audit fee to compensate higher risk (the higher the risk, the higher the expected return). Once again, opportunistic income smoothing is considered to have higher risk than the non-opportunistic income smoothing.

Figure 3 shows that as (non-opportunistic) income smoothing tendency declines, the 
probability of companies to choose big audit firm increases. This is consistent with the positive regression coefficient sign of ABSEFE that the greater the absolute value of earnings forecast errors, the lower the (non-opportunistic) income smoothing tendency, and ultimately the greater the probability of companies to choose big audit firm. Figure 3 also comprises three important parts. The first part is when odds ratio is less than one, the second part is when odds ratio equals one, and the last part is when odds ratio is greater than one

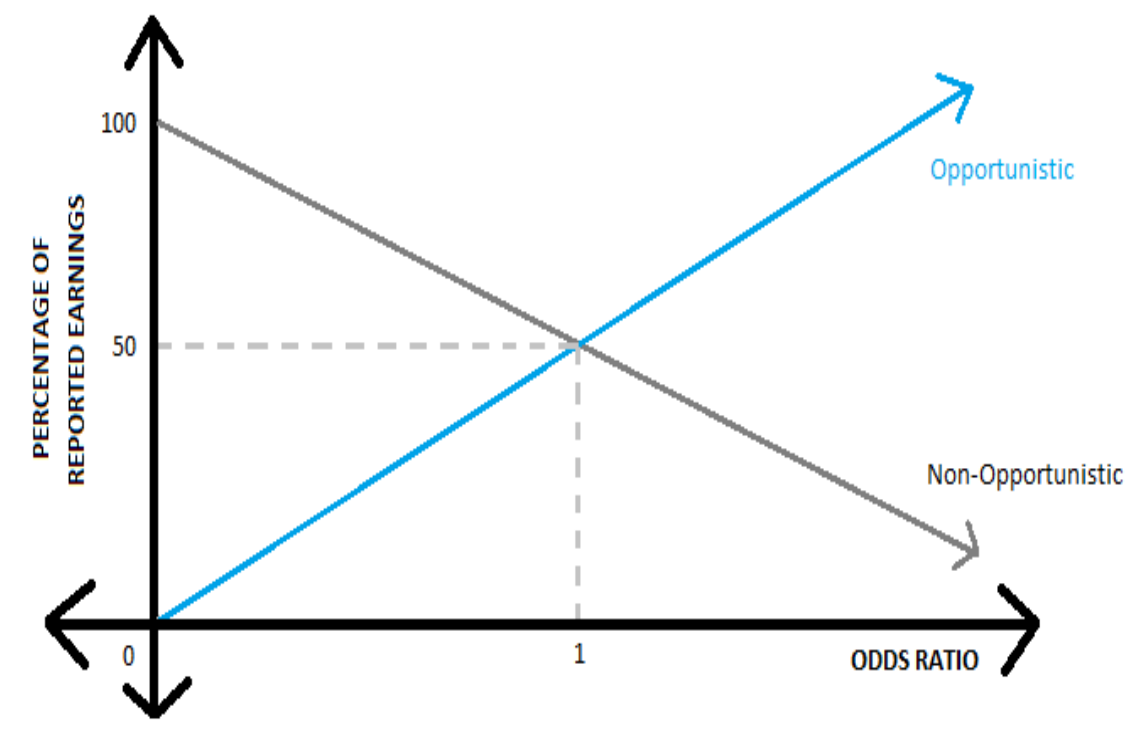

Figure 3. Illustration about the Relationship between Types of Income Smoothing and Odds Ratio in Weak Litigation Environment

In the first part, in a situation where financial statements are prepared in accordance with accounting standards (non-opportunistic income smoothing tendency), the company might not need to obtain audit opinion from big audit firm in order to increase the reliability of its financial statements (holding other factors constant). This is why, according to the first part of the figure above, the probability of companies to choose non-big audit firms is greater than that of big audit firms when non-opportunistic income smoothing tendency is greater than the opportunistic income smoothing tendency.

In the second part, when the proportion of non-opportunistic income smoothing equals the opportunistic income smoothing tendency, the odds ratio equals one. This odds ratio indicates that companies have indifferent preference to audit firm size. This condition applies both in strong and weak litigation environment. Therefore, from the perspective of ABSEFE's odds ratio, it is unclear yet about the litigation environment in Indonesia.

Lastly in the third part, in weak litigation environment, companies with lower non-opportunistic income smoothing tendency tend to choose big audit firms (alternatively speaking, big audit firms may accept audit offer from companies with greater opportunistic income smoothing tendency) with higher audit fee with a hope of having an increase in the reliability of its financial statements (holding other factors constant). In real-world practices, the same audit opinion from big audit firms is valued higher than that from non-big audit firms. From this reason, companies with greater risk (greater portion of opportunistic income 
smoothing tendency) would tend to choose big audit firm with higher cost to avoid negative sentiment from stakeholders. In other words, brand-name auditor may become effective firm's value control mechanism in weak litigation environment. If this is true, auditor independence is under a serious threat.

\subsection{Risk Tolerance and Audit Firm Size}

Dummy variable of risk tolerance on Table 5 and 7 consistently shows positive and significant effect on audit firm size. In addition to the positive coefficient sign and significant p-value, odds ratio of more than 11.00 on Table 7 indicates that companies with intolerable risk have greater probability to choose big audit firm with the magnitude of about 11 times higher.

Table 7. Logit Regression of Risk Tolerance and Audit Firm Size

\begin{tabular}{|c|c|c|c|c|c|c|c|c|}
\hline \multirow{3}{*}{ Variables } & \multicolumn{8}{|c|}{ Dependent Variable: DAUDITOR } \\
\hline & \multicolumn{4}{|c|}{ Before Control Variable } & \multicolumn{4}{|c|}{ After Control Variable } \\
\hline & $\begin{array}{l}\text { Coef } \\
\text { (S.E) }\end{array}$ & z-Stat & Sig & Odds Ratio & $\begin{array}{l}\text { Coef } \\
\text { (S.E) }\end{array}$ & z-Stat & Sig & Odds Ratio \\
\hline Intercept & $\begin{array}{c}0.054 \\
(0.048033)\end{array}$ & 1.128 & 0.259 & 1.055 & $\begin{array}{l}-1.62096 \\
(0.61016)\end{array}$ & -2.657 & 0.079 & 0.198 \\
\hline DTOL & $\begin{array}{c}2.39897 \\
(0.171632)\end{array}$ & 13.98 & 0.000 & 11.01 & $\begin{array}{c}2.4150 \\
(0.1719)\end{array}$ & 14.05 & 0.000 & 11.19 \\
\hline SIZE & & & & & $\begin{array}{c}0.137812 \\
(0.05)\end{array}$ & 2.753 & 0.006 & 1.15 \\
\hline Pseudo $\mathrm{R}^{2}$ & \multicolumn{4}{|l|}{0.107001} & \multicolumn{4}{|l|}{0.109545} \\
\hline $\mathrm{N}$ & \multicolumn{4}{|l|}{2,240} & \multicolumn{4}{|l|}{2,240} \\
\hline
\end{tabular}

Source: Output of EViews

Note: The parentheses are the standard errors of corresponding variables. Odds ratio is the exponential form of regression coefficient $[\operatorname{Exp}(\quad)]$

Companies with intolerable risk (those with high business and financial risks) tend to choose big audit firms because they expect to have better image and more positive market response from the users of financial statements. To deal with this, they have to pay higher fees which indicate that companies with greater asset size tend to choose big audit firms. Alternatively speaking, big audit firms accept audit offer from companies with high business and financial risk. From previous explanation, this confirms that litigation environment in Indonesia is weak. In weak litigation environment, the cost of litigation is not high so that audit firms may diversify their portfolio of clients. Having clients with higher risk should be followed by higher audit fee in order to compensate the risk exposure. Another implication from this finding is that non-big audit firm in Indonesia is less capable of accepting risky client due to weaker monitoring strength. Meanwhile, the control variable of client's asset size (SIZE) consistently shows positive coefficient sign, significant p-value, and odds ratio of greater than 
1.00 on Table 5, Table 6, and Table 7. These statistical findings suggest that clients with greater asset size tend to choose big audit firm.

\section{Conclusion}

This research contributes to an alternative measurement of income smoothing tendency and company risk. Income smoothing tendency is measured by the absolute value of differences between the reported after-tax profits and the estimated after-tax profits from 2007 to 2013 resulted from ordinary least square regression of observed or reported after-tax profits and the period of reported profits from 2007 to 2013. Meanwhile, risk tolerance is measured by dummy variable of risk tolerance ( 1 if the company has intolerable risk, which is when the company has both high business and financial risks; and 0 if it has tolerable risk, which is when the company has both low business and financial risks, or when the company either has low business risk but high financial risk or high business risk but low financial risk), in which business risk and financial risk are classified high or low based on each company risk relative to its appropriate industry. Business risk is measured by the standard deviation of profit before interests and taxes in four quarterly reporting periods of each company and classified as high (low) if the company's business risk is higher than or equal to (lower than) the average business risk of the industry where the company runs it business. Meanwhile, financial risk is measured by the ratio of total debt to total equity and classified as high (low) if the company's financial risk is higher than or equal to (lower than) the average financial risk of the industry where the company runs it business.

Companies with greater absolute value of earnings forecast errors or lower tendency of income smoothing tend to choose big audit firms because big audit firms have greater monitoring strength which lower the probability of clients to commit opportunistic earnings management. Meanwhile, companies with intolerable risk (those with high business and financial risks) tend to choose big audit firms because they expect to have better image and more positive market response from the users of financial statements. To deal with this, they have to pay higher fees which indicate that companies with greater asset size tend to choose big audit firms. This research partially supports Beatty (1986), that big audit firms or brand name auditors tend to provide audit services to clients with greater asset size, but this research finds that clients with intolerable risk tend to choose big audit firms which opposes Beatty's finding (1986) that big audit firms prefer clients with lower financial and litigation risks. This research also implicitly finds that non-big audit firms are not capable of providing audit services to intolerable risk companies and litigation environment in Indonesia is not strong, as suggested by Datar, Feltham, \& Hughes (1991), and Clarkson \& Simunic (1994). They found that in less strong litigation environment, clients choosing big audit firms tend to have greater risk.

\section{Acknowledgement}

This paper was initially entitled Income Smoothing Tendency, Risk Tolerance, and Audit Firm Size and presented in $1^{\text {st }}$ International Conference on Business, Economics, and Social Sciences at the Grand Inna Kuta Hotel, Bali (25 - 26 June 2014). Current version involves greater number of observations (2,240 company-year observations) whereas the previous 
version was with 1,500 company-year observations. I am very grateful for comments from conference participants. I remain responsible for any remaining errors or omissions.

\section{References}

Bachar, J. (1989). Auditing Quality, Signaling, and Underwriting Contracts. Contemporary Accounting Research, 6(1), 216-241. http://dx.doi.org/10.1111/j.1911-3846.1989.tb00754.x

Beatty, R.P. (1986). The Initial Public Offerings Market for Auditing Services. Auditing Research Symposium at the University of Illinois.

Beatty, R.P. (1989). Auditor Reputation and the Pricing of Initial Public Offerings. The Accounting Review, 64, 693-709.

Becker, C.L., DeFond, M.L., Jiambalvo, J., \& Subramanyam, K.R. (1998). The Effect of Audit Quality on Earnings Management. Contemporary Accounting Research, 15(1), 4-24. http://dx.doi.org/10.1111/j.1911-3846.1998.tb00547.x

Benston, G.J. (1969). The Value of the SEC's Accounting Disclosure Requirements. The Accounting Review, 44, 515-532.

Burgstahler, D., \& Dichev, I. (1997). Earnings Management to Avoid Earnings Decreases and Losses. Journal of Accounting and Economics, 24(1), 99-126. http://dx.doi.org/10.1016/S0165-4101(97)00017-7

Clarkson, P.M., \& Simunic, D.A. (1994), The Association Between Audit Quality, Retained Ownership, and Firm Specific Risk in US vs Canadian IPO Markets. Journal of Accounting and Economics, 17, 207-228. http://dx.doi.org/10.1016/0165-4101(94)90010-8

Craswell, A., Francis, J., \& Tylor, S. (1995). Auditor Brand Name Reputation and Industry Specializations. Journal of Accounting and Economics, 20, 297-322. http://dx.doi.org/10.1016/0165-4101(95)00403-3

Datar, S.M., Feltham, G.A., \& Hughes, J.S. (1991), The Role of Audits and Audit Quality in Valuing New Issues. Journal of Accounting \& Economics, 14, 3-49. http://dx.doi.org/10.1016/0167-7187(91)90057-R

Davidson, R.A., \& Neu, D. (1993). A Note on the Association Between Audit Firm Size and Audit Quality. Contemporary Accounting Research, 9, 479-488. http://dx.doi.org/10.1111/j.1911-3846.1993.tb00893.x

DeAngelo, L. (1981). Auditor Size and Auditor Quality. Journal of Accounting \& Economics, 12, 183-199. http://dx.doi.org/10.1016/0165-4101(81)90002-1

Dechow, P., Sloan, R., \& Sweeney, A. (1995). Detecting Earnings Management. The Accounting Review, 70, 193-225.

DeFond, M.L. (1992). The Association Between Changes in Client Firm Agency Costs and Auditor Switching. Auditing: A Journal of Practice and Theory, 11, 16-31.

Degeorge, F., Patel, J., \& Zeckhauser, R. (1999). Earnings Management to Exceed Thresholds. 
Journal of Business, 72(1), 1-33. http://dx.doi.org/10.1086/209601

Dopuch, N., \& Simunic, D. (1982). Competition in Auditing: An Assessment. Fourth Symposium on Auditing Research, University of Illinois.

Francis, J.R., \& Wilson, E.R. (1988). Auditor Changes: A Joint Test of Theories Relating to Agency Costs and Auditor Differentiation. The Accounting Review, 63 (October), 663-682.

Jensen, M.C., \& Meckling, W.H. (1976). Theory of the Firm: Managerial Behaviour, Agency Costs, and Ownership Structure. Journal of Financial Economics, 3, 305-360. http://dx.doi.org/10.1016/S0022-5193(76)80085-9

McNichols, M.F., \& Stubben, S.R. (2008). Does Earnings Management Affect Firms Investment Decisions?. The Accounting Review, 83(6), 1571-1603. http://dx.doi.org/10.2308/accr.2008.83.6.1571

Palmrose, Z. (1984). The Demand for Quality-Differentiated Audit Services in an Agency Cost Setting: An Empirical Analysis. Proceedings of the Sixth Symposium on Auditing Research, Abdel-Khalik A.R., \& Solomon, I (Ed). Champaign: University of Illinois Press: 229-252.

Reilly, F.K., \& Brown, K.C. (2009). Investment Analysis and Portfolio Management. $9^{\text {th }}$ Edition. South-Western CENGAGE Learning.

Scott , W. (2000), Financial Accounting Theory. Prentice Hall, Chapter 11, 343-352.

Stubben, S. (2008), Discretionary Revenues as a Measure of Earnings Management. Working Paper, The University of North Carolina at Chapel Hill.

Tucker, J.W., \& Zarowin, P.A. (2006), Does Income Smoothing Improve Earnings Informativeness?. The Accounting Review, 81(1), 251-270. http://dx.doi.org/10.2308/accr.2006.81.1.251

Watts, R.L., \& Zimmerman, J.L. (1978), Towards a Positive Theory of the Determination of Accounting Standard. The Accounting Review, 1, 112-134.

Watts, R.L., \& Zimmerman, J.L. (1983). Agency Problems, Auditing, and the Theory of the Firm: Some Empirical Evidence. The Journal of Law \& Economics, 10, 613-633. http://dx.doi.org/10.1086/467051

\section{Copyright Disclaimer}

Copyright for this article is retained by the author(s), with first publication rights granted to the journal.

This is an open-access article distributed under the terms and conditions of the Creative Commons Attribution license (http://creativecommons.org/licenses/by/3.0/). 